\title{
Relasi media sosial dan pasar dalam perubahan nilai publik mengenai pengaruh dakwah di media sosial terhadap pandangan gaya hidup halal
}

\author{
Kurnia Rheza Randy Adinegoro* \\ Magister Kepemimpinan dan Inovasi Kebijakan, Sekolah Pascasarjana, Universitas Gadjah \\ Mada, Yogyakarta, 55281, Indonesia.
}

\begin{abstract}
ABSTRAK
Pada era ini, teknologi khususnya sistem komunikasi berkembang dengan pesat. Perkembangan tersebut banyak memberi dampak bagi kehidupan di masyarakat. Salah satunya adalah penggunaan media sosial dalam kehidupan sehari-hari. Pemanfaatan media sosial ini juga dimanfaatkan dalam usaha untuk menyebarkan ajaran agama, salah satunya dakwah agama Islam. Dengan adanya dakwah agama Islam yang dekat dan mudah diakses oleh umat Islam, hal ini akan memberi pengetahuan agama yang bermanfaat. Dari berbagai pengetahuan atau hal yang didakwahkan, salah satunya adalah pengetahuan tentang halal. Dakwah mengenai kehalalan suatu produk tersebut banyak mengubah pandangan umat muslim untuk lebih memperhatikan gaya hidup terkhusus gaya hidup halal. Gaya hidup halal adalah sebuah ciri khas yang dimiliki oleh konsumen beragama Islam. Kosumen yang beragama Islam akan menjaga barang yang dikonsumsi. Mereka akan memilih produk halal baik secara zat maupun secara mekanisme perolehannya. Oleh karena itu, pasar harus tanggap dalam merespon apa yang diminta oleh masyarakat. Pasar harus menjawab permintaan gaya hidup halal dari masyarakat, baik di sektor konsumsi maupun non konsumsi. Apa yang dimaksud halal tidak hanya dinilai dari segi syariat saja, tetapi juga harus dilihat dari perspektif nilai yang lebih umum, seperti kesehatan, keselamatan, dan kebersihan.
\end{abstract}

Kata kunci: Dakwah media sosial, Gaya hidup halal, Halal, Media sosial, Nilai publik.

(C) 2022 Pusat Kajian Halal ITS. All rights reserved.

\section{Pendahuluan}

Perkembangan teknologi dan sistem komunikasi di dunia saat ini berkembang secara pesat. Kemajuan teknologi ini membawa berbagai dampak perubahan. Dampak tersebut meluas ke semua wilayah negara tidak terkecuali juga di Indonesia. Segala aspek dalam kehidupan mulai tersentuh transformasi digital. Salah satu perkembangan digital yang masif adalah media sosial. Media sosial seakan memberi ruang untuk siapa saja untuk ikut serta dengan memberi umpan balik secara terbuka [1]. Umpan balik tersebut dapat berupa komentar, mengunggah ulang, atau like-dislike. Media sosial mempunyai dampak yang besar, bisa membuat orang terkenal dengan mudahnya bahkan membenci orang tertentu tanpa mengenalnya terlebih dahulu. Dalam istilah anak muda Jakarta Selatan, media sosial banyak mempunyai influencer

\footnotetext{
* Corresponding author. Tel: +6282228015858; Fax: -.

Email address: rhezarndy@gmail.com
} 
sebagai toxic positivity dan buzzer sebagai toxic negativity. Membuka media sosial adalah sebuah rutinitas di saat ini apalagi bagi para remaja. Ibarat tiada hari tanpa membuka media sosial [1].

Dampak perkembangan teknologi ini juga terjadi pada sektor dakwah Islam. Potensi media sosial juga dapat dimanfaatkan oleh para pendakwah agama Islam dalam menyebarkan ajaran Islam. Perlu diketahui bahwa Indonesia merupakan salah satu negara dengan penduduk beragama Islam terbesar di dunia berdasarkan data dari Badan Pusat Statistik (BPS) pada Sensus Penduduk 2010. Indonesia berada pada rangking paling atas sebagai negara beragama Islam, di mana terdapat sekitar 207 juta orang dan itu merupakan mayoritas dengan presentase $87,18 \%$ dari total penduduknya [2].

Dakwah dalam Islam mempunyai kedudukan yang sangat penting. Dakwah juga disebut sebagai tarbiyah. Bedanya, tarbiyah berarti mendidik, sedangkan dakwah artinya mengajak atau menyeru. Pada intinya, kedua istilah tersebut adalah sama dengan maksud amar ma'ruf nahi mungkar atau mengajak kebaikan mencegah kejahatan. Hubungan antara mengajak kebaikan dan mencegah kejahatan sangat erat dan tidak bisa dipisahkan. Disebutkan dalam QS. Ali Imran Ayat 104 "dan hendaklah ada di antara kamu segolongan umat yang menyeru kepada kebajikan, menyuruh kepada yang ma'ruf dan mencegah dari yang munkar, merekalah orang-orang yang beruntung".

Untuk menjawab tantangan zaman, media berdakwah harus terus adaptif dengan memanfaatkan teknologi informasi. Fungsi dasar teknologi informasi adalah keikutsertaan manusia untuk saling berkomunikasi. Model komunikasi yang dibentuk juga melibatkan banyak manusia. Antara satu dengan lainnya bisa saling bertukar informasi, bertukar pikiran atau menjadi wadah berdiskusi tanpa harus bertatap muka [3]. Hal ini tentunya akan menjadi suatu hal yang cocok dalam penyebaran dakwah di era pandemi covid-19.

Kemudahan dalam mengakses dakwah pengetahuan agama Islam tentunya akan mempengaruhi pandangan terhadap nilai publik. Konsep nilai publik adalah suatu multidimensi sebagai gambaran dan perwajahan masyarakat, yang diciptakan melalui sebuah proses yang dapat menghasilkan kepercayaan dan kesetaraan [4]. Perubahan nilai publik ini tidaklah singkat, tetapi ada fase-fase tertentu dalam perjalanannya. Dakwah yang mudah diakses tentunya bisa menjadi salah satu faktor yang mengeskalasi perubahan tersebut. Salah satunya adalah perubahan mengenai nilai halal atau dapat dikatakan pandangan gaya hidup halal.

Salah satu dakwah yang masif dilakukan di media sosial adalah yang berkaitan dengan pandangan mengenai halal dan haramnnya suatu produk. Pandangan mengenai hal tersebut sedikit banyak akan mengubah perilaku konsumsi di masyarakat. Sesuai dengan hukum ekonomi bahwa jika terjadi peningkatan permintaan maka akan berpengaruh kepada penawaran. Ketika permintaan dan penawaran tersebut bertemu maka pasar akan terbentuk. Tidak terkecuali pasar halal di Indonesia. Ketika permintaan produk halal meningkat maka akan terjadi peningkatan investasi pada penyedia produk halal.

Media sosial yang sangat dekat dan mudah diakses dapat mempengaruhi aspek kultural, sosial, personal dan karakteristik psikologis perilaku konsumen. Pada dasarnya gaya hidup 
halal bermakna luas dan hal yang paling sederhana dan paling mudah ditemukan adalah membeli ataupun mengkonsumsi produk yang halal [5]. Selain hal tersebut juga mencakup perilaku sehari-hari yang dilakukan, seperti berbuat baik, mencari rejeki dengan tidak korupsi, tidak menipu, dan sebagainya.

Gaya hidup halal adalah pola hidup seseorang yang diekspresikan dalam aktivitas, minat, dan opininya terhadap barang yang halal pada masyarakat, baik yang beragama Islam maupun non Islam. Masyarakat yang beragama Islam tentu akan menjaga konsumsinya terhadap barang yang halal, baik dari bahan pembuatannya ataupun proses produksinya. Apalagi dengan semakin dimudahkan dalam mengakses pengetahuan mengenai pemahaman Islam dalam dakwah di media sosial. Berdasarkan uraian latar belakang, maka tulisan ini membahas mengenai pengaruh dakwah di media sosial terhadap transformasi pasar dalam perubahan nilai publik mengenai pandangan gaya hidup halal.

\section{Metode}

Metode pengumpulan data dalam penulisan ini adalah melalui studi kepustakaan atau literatur. Studi literatur merupakan studi yang berkaitan dengan suatu kajian yang teoritis dan referensi lainnya yang berkaitan dengan nilai, norma, ataupun budaya dari perkembangan situasi sosial yang tengah diamati [6]. Sumber-sumber literatur dalam tulisan ini adalah melalui dokumen, buku, ataupun sumber bahan pustaka lainnya yang berkaitan dan mendukung bahasan tulisan ini.

\section{Hasil dan diskusi}

\subsection{Perubahan nilai publik}

Perubahan dalam masyarakat adalah keniscayaan yang tidak dapat dihindarkan, prosesnya berjalan secara terus-menerus. Proses perubahan ini tidaklah sama antara kelompok satu dengan kelompok lainnya. Hal tersebut dapat terjadi karena tentu banyak faktor atau latar belakang yang mempengaruhi perubahan itu sendiri [7]. Moore menyatakan bahwa nilai publik megacu pada nilai yang diciptakan oleh pemernitah melalui peraturan hukum dan tindakan yang lainnya.

Nilai publik tercipta dari sebuah kebiasaan yang berproses dan diterima oleh masyarakat serta mempengaruhi tatanan kehidupan bermasyarakat. Hal tersebut terus dilakukan secara berulang sehingga menjadi sebuah tatanan nilai publik. Perubahan adalah suatu keniscayaan dan suatu hal yang tidak bisa dihindarkan dalam kehidupan. Begitu pula perubahan nilai publik akan terus terjadi seiring dengan kehidupan bermasyarakat.

\subsection{Relasi pasar dan dakwah media sosial terhadap pandangan gaya hidup halal}

Pandemi Covid-19 yang terjadi sejak 2020 menyebabkan adanya pembatasan kegiatan masyarakat. Salah satunya adalah larangan untuk berkerumun, bahkan sampai adanya lockdown yang menyebabkan pembatasan kegiatan. Tidak terkecuali kegiatan keagamaan agama Islam. Seakan-akan manusia dilatih untuk berubah dan menjadi digital dengan waktu yang sangat cepat. Perubahan ini jugaterjadi dalam sektor keagamaan, salah satunya dakwah. Dakwah yang dahulu dilakukan dengan metode luring/tatap muka saat ini bergeser ke daring 
melalui media sosial. Dakwah melalui media sosial sebagai salah satu cara agar para pendakwah tetap dapat berdakwah dan menyampaikan ajaran-ajaran Islam.

Kemudahan dalam mengakses media dakwah ini juga dimanfaatkan oleh umat Islam dalam mendalami kehidupan syariahnya. Salah satunya menyangkut mengenai gaya hidup. Dakwah melalui media sosial ini sangat berpengaruh dan bermanfaat agar tetap mempertahankan nilai publik yang sesuai dengan aturan yang ada dalam agama Islam [8].

Gaya hidup adalah sebuah pola tingkah laku sehari-hari dan/atau cara seseorang maupun sekelompok orang di dalam masyarakat untuk menjalani kehidupan sebagaimana keyakinannya. Dalam keyakinan syariat Islam, setiap perilaku yang dilakukan dan diperbuat harus bersumber dari Al-Qur'an dan Hadist. Sehingga dapat ditarik kesimpulan bahwa gaya hidup halal adalah gaya hidup yang mencerminkan sikap dan perilaku dengan mengilhami dan menerapkan nilai Islam dalam setiap aktivitasnya, baik aktivitas sosial, ekonomi, budaya, dan lainnya [9].

Halal dalam arti sempit yang dipahami sehari-hari adalah segala sesuatu yang diperbolehkan atau tidak dilarang oleh syariat agama Islam. Sebagaimana selama ini halal dipahami dengan segala sesuatu yang berasosiasi pada sektor makanan dan minuman. Sebagaimana contoh seperti daging ayam atau minuman yang tidak mengandung alkohol. Kata halal dan haram adalah istilah di dalam kitab suci Al-Qur'an dan digunakan dalam makna konotasi luas tidak hanya sekedar berkaitan dengan makanan dan minuman namun juga konsep yang luas [5]. Halal juga dapat dikatakan sebagai gaya hidup, di mana umat Islam harus memilih saat mereka membeli produk dan/atau layanan yang sesuai dengan hukum syariah dan norma Islam itu sendiri.

Keadaan lingkungan, budaya, dan kondisi kehidupan adalah beberapa faktor yang menentukan gaya hidup seseorang. Namun, pada era digital ini dan dengan adanya faktor pandemi covid-19, masyarakat lebih disarankan berinteraksi dengan platform digital. Sehingga konten-konten yang ada pada media sosial bisa mempengaruhi gaya hidupnya. Tidak terkecuali konten mengenai dakwah yang membahas gaya hidup halal. Melalui pengetahuan yang didapat dari dakwah media sosial dapat menjadi kebiasaan dalam kehidupan sehari-harinya untuk membeli produk dan/atau layanan yang sesuai dengan dengan nilai-nilai serta prinsip syariat Islam.

Hal yang pertama dalam membangun pola gaya hidup halal adalah sebuah kesadaran. Dengan kesadaran itu akan terbangun pola dan kebiasaan untuk mengkonsumsi atau membeli produk halal. Lebih dari itu, kesadaran akan produk halal juga akan diaplikasikan dalam transaksi keuangan. Transaksi keuangan akan sebisa mungkin menjauh dari unsur yang diharamkan seperti riba, gharar, atau dalam bahasa jawa sering disebut ngijon, dan lain sebagainya.

Gaya hidup halal dewasa ini popular dan banyak diaplikasikan di seluruh dunia, tidak hanya Indonesia yang notabene adalah negara mayoritas muslim namun juga di negara dengan penduduk yang muslimnya menjadi minoritas [10]. Faktor yang membuat gaya hidup halal dirasa penting tercermin dari apa yang didapat ketika masyarakat mengkonsumsi produk halal. Mereka yang mengonsumsi produk halal akan merasa tenang dan nyaman karena meyakini prosesnya sudah sesuai dengan syariat islam dan pasti dijamin bersih higienis. 
Olehnya masyarakat yang sudah mendapat manfaat tersebut akan menjadikan halal sebagai pilihan dalam membeli makanan atau produk tertentu. Halal akan menjadi sebuah dasar yang mengakar dan lebih dari gaya hidup yaitu pandangan hidup.

Implementasi gaya hidup halal ini seperti yang sudah dijelaskan diawal tulisan ini akan membentuk sebuah pasar dimana masyarakat akan mengimplementasikan nilai syariat Islam di kehidupan sehari-hari. Artinya masyarakat yang seperti ini akan memilih dalam melakukan aktivitasnya, baik memilih produk maupun aktivitas ekonominya. Indonesia dapat dikatakan sudah memiliki sarana pendukung dalam penerapan gaya hidup halal, di antaranya dengan adanya beberapa lembaga seperti LPPOM MUI dan BPJPH [9].

Oleh karena itu, pasar harus tanggap dalam merespon apa yang diminta oleh masyarakat. Pasar harus menjawab permintaan dari masyarakat, baik di sektor konsumsi, maupun non konsumsi seperti kosmetik, keuangan, media, fashion dan pakaian, perjalanan, pariwisata, produk elektronik dan sebagainya.

\subsection{Pandangan produk halal non konsumsi}

Indonesia sudah mempunyai infrastruktur untuk mengaplikasikan gaya hidup halal dengan adanya beberapa lembaga seperti Lembaga Pengkajian Pangan Obat-obatan dan Kosmetika Majelis Ulama Indonesia (LPPOM MUI) dan Badan Penyelenggara Jaminan Produk Halal (BPJPH) sebagaimana sudah disebutkan di atas.

BPJPH bertugas mengeluarkan status halal suatu produk atau layanan berdasar fatwa halal yang dikeluarkan oleh LPPOM MUI. Fatwa ini keluar dengan diadakan rapat yang dihadiri oleh anggota komisi fatwa MUI dan dalam rapat tersebut akan dipertimbangkan dampak maslahah (kebaikan) dan menghilangkan bahaya (kemudaratan).

MUI telah mempunyai standarisasi bagaimana produk yang dikategorikan produk halal sebagaimana produk yang sesuai dengan syariat Islam. Produk tersebut harus terbebas dari kandungan babi (bahannya atau proses pembuatannya), tidak mengandung organ manusia, darah, ataupun kotoran-kotoran yang diharamkan. Selain itu jika produknya adalah daging proses penyembelihannya harus sesuai dengan tata cara syariat Islam. Penyimpanan, pengolahan sampai dengan distrubusi produk juga diperhatikan. Untuk produk minuman harus tidak mengandung alkohol dan yang bisa memabukkan [11].

Sertifikasi label halal sering ditemui dalam beberapa produk maupun industri makanan. Namun, seiring berjalannya waktu, ini juga bisa ditemui di produk non konsumsi seperti detergen, peralatan masak, bahkan MUI mengeluarkan fatwa halal pada produk elektronik berupa lemari es bernama dagang SHARP dari PT. Sharp Indonesia.

Langkah yang diambil dari Sharp merupakan salah satu tanggapan pasar dalam menjawab gaya hidup halal di masyarakat. Perusahaan tentunya mengajukan sertifikasi label halal tak lain bertujuan untuk memberikan perlindungan, rasa nyaman dan aman ketika membeli produk mereka. Selain itu, untuk menjadi sebuah nilai tambah produk, masyarakat dapat menentukan pilihan produk sesuai dengan gaya hidup halal. 
Mekanisme sertifikasi label halal MUI pada produk non konsumsi, dalam hal ini produk elektronik, dilakukan oleh pelaku industri kepada LPPOM MUI. Pelaku industry terlebih dahulu menerapkan sistem jaminan halal pada produknya, yakni kebijakan yang halal, tim manajemen yang halal, material yang digunakan dipastikan halal, prosedur tertulis perusahaan, penanganan perusahaan atas barang yang tidak memenuhi syarat, audit internal, dan manajemen review. Setelah itu akan dilakukan verifikasi fasilitas produk, yang kemudian hasilnya akan didiskusikan oleh internal MUI. Terakhir, sertifikat halal produk elektronik dan non konsumsi dapat dikeluarkan [11].

Bukan tanpa penolakan, kritik pernah dilayangkan oleh Wijayanto Samirin selaku Staf Khusus Wakil Presiden Bidang Ekonomi dan Keuangan. Menurut beliau, lemari es bersertifikasi halal adalah sebuah salah kaprah. Beliau mengacu pada Pasal 1 ayat (1) Undang-Undang Nomor 33 Tahun 2014 tentang Jaminan Produk Halal terkait barang gunaan yang meliputi pakaian, sepatu, tas yang mengandung unsur hewani seperti bulu, kulit, dan tulang. Di sisi lain, sertifikasi label halal pada suatu produk khususnya non konsumsi tentunya akan memudahkan bagi masyarakat untuk memilih suatu produk sebagaimana yang disyaratkan dalam syariat Islam. Konsep ekonomi Islam meyakini bahwa ketika konsumen melakukan konsumsi atau membeli produk, serta melakukan kegiatan yang bergantung pada nilai agama (halal), maka mereka akan merasa puas. Dengan begitu, masyarakat dapat memenuhi kepuasannya yaitu dengan membeli alternatif produk halal [12]. Pandangan halal itu luas bukan hanya pada sisi nilai syariat Islam, tetapi juga mencakup hal yang lebih umum, seperti kebersihan, keselamatan, dan kesehatan. Dengan demikian konsep halal yang diterapkan tidak hanya dirasakan dampaknya bagi umat muslim, tapi juga non muslim [13].

\section{Kesimpulan}

Perubahan nilai terjadi secara terus menerus, yang tercipta dari sebuah kebiasaan yang berkembang dan diterima oleh masyarakat, serta berpengaruh pada tatanan kehidupan masyarakat. Dakwah melalui media sosial sebagai salah satu cara agar para pendakwah dalam merespon kemajuan jaman. Olehnya masyarakat dapat dengan mudah mengakses media dakwah dari gawainya masing-masing agar dapat dimanfaatkan untuk mendalami kehidupan sesuai syariat Islam. Salah satunya menyangkut gaya hidup halal. Penerapan gaya hidup halal ini membentuk sebuah pasar di mana masyarakat akan mengimplementasikan nilai syariat Islam di kehidupan sehari-hari. Oleh karena itu, pasar harus tanggap dalam merespon permintaan masyarakat akan produk halal, yaitu di sektor konsumsi dan non konsumsi seperti kosmetik, keuangan, media, fashion dan pakaian, perjalanan, pariwisata, produk elektronik dan sebagainya. MUI telah mempunyai standarisasi bagaimana produk yang dikategorikan produk halal. MUI menganggap perlu dilakukan sertifikasi produk halal non makanan karena menyangkut aspek perlindungan pada konsumen khususnya umat Islam dan aspek legalitas hukum.

\section{Referensi}

[1] W.S.R. Putri, N. Nurwati, dan M. Budiarti, "Pengaruh media sosial terhadap perilaku remaja," Prosiding KS: Riset \& PKM, vol. 3, no. 1, pp. 47-51, 2016.

[2] Badan Pusat Statistik, "Penduduk Menurut Wilayah dan Agama yang Dianut," 2010. https://sp2010.bps.go.id/index.php/site/tabel?tid=321 (diakses 20 Desember 2021). 
[3] Y. Purwanto, M. Taufik, A.W. Jatnika, "Peran teknologi informasi dalam perkembangan dakwah mahasiswa," J. Sosioteknologi, vol. 16, no. 1, pp. 94-109, 2017.

[4] J. Alford dan J. O'Flynn, "Making sense of public value: Concepts, critiques and emergent meanings," Int. J. Public Adm., vol. 32, no. 3-4, pp. 171-191, 2009, doi: 10.1080/01900690902732731.

[5] M. Ali, "Konsep makanan halal dalam tinjauan syariah dan tanggung jawab produk atas produsen industri halal," AHKAM J. Ilmu Syariah, vol. 16, no. 2, pp. 291-306, 2016, doi: 10.15408/ajis.v16i2.4459.

[6] P.D. Sugiyono, Metode Penelitian Pendidikan: Pendekatan Kuantitatif, Kualitatif, R\&D. Bandung: CV. Alf, 2016.

[7] R. Hatu, "Perubahan sosial kultural masyarakat pedesaan," Inovasi, vol. 8, no. 4, pp. 111, 2011.

[8] A. Fauzi dan E. Maghfiroh, "Problematika dakwah di tengah pandemi covid-19," no. 1, pp. 23-32, 2020.

[9] A.N. Rohim dan P.D. Priyatno, "Consumption patterns in the implementation of halal," vol. 4, no. November, pp. 26-35, 2021.

[10] A.S. Hidayat, M. Siradj, dan J. Selatan, "Sertifikat halal dan non halal pada produk pangan industri," J. Ahkam, vol. XV, no. 2, pp. 199-210, 2015.

[11] Hatoli, "Sertifikasi halal Majelis Ulama Indonesia pada produk elektronik dan non konsumsi perspektif maslahah," J. Islam. Law, vol. 1, no. 2, pp. 237-255, 2020, doi: 10.24260/jil.v1i2.45.

[12] A. Bahri, "Etika konsumsi dalam perspektif ekonomi islam," J. Stud. Islam., vol. 11, no. 2, pp. 347-370, 2014.

[13] H.H. Adinugraha, M. Sartika, dan A.H.A. Ulama'i, "Halal lifestyle di indonesia," J. Ekon. Syariah, vol. 5, no. April, pp. 57-81, 2019. 